\title{
Reticent Testimony of Survivors: Contemplating Holocaust through Memoirs
}

\author{
Rashmi Malik \\ Dept. of English and Foreign Languages Maharshi Dayanand University Rohtak.
}

\begin{abstract}
The Holocaust, the heinous crime of the $20^{\text {th }}$ century, happened only seventy years ago, so it can be considered recent. The survivors feel crestfallen as they had to rejoin the same society, which was an accomplice either by commission or omission to the 'insolent logic' of 'final solution'. Going through Holocaust writings, a sense of disbelief, incomprehensibility, obscurity and exclusivity is perceived. The memoirs give an incisive and interpretive account of the lives lost. There is no screaming, no anger, but an assertion for the dignity of those perished in this genocide.

Keywords: Anti-Semitism, concentration camps, Holocaust, memoir, Nazism, silence and testimony.
\end{abstract}

\section{Text}

Sifting the pages of history we come across inexplicable facts that impugn the incidents transpired in antiquity. As suggested by various data, the Jews represented less than one percent of Germany's 5.2 million population in 1933. Approximately three lakh Jews emigrated from Germany during the earlier years of Nazi dictatorship when anti-Semitism became increasingly unendurable. Earlier the Jews had prominent positions in the government organizations and renowned universities of Germany. It is a heartening fact that of the thirty eight Nobel Prizes awarded to German scientists and writers between 1905 and 1936, 14 went to Jews. The paradox lies in the fact that over one lakh Jews fought for Germany in World War I and received medals for valour in combat. But something was lurking inside and its manifestation was evident in a German Decree issued on August 17, 1938 that required all German Jews to have German names so that they could be differentiated clearly. And after that the world changed forever for the Jews, as no civilized world existed for them any more.

In a speech in 1943 Abraham Joshua Heschel, a Polish born Jewish philosopher, decried a sense of mistrust among the human beings with a powerful rhetoric saying, "At no time has the earth been so soaked with blood. Fellowmen turned out to be evil ghosts, monstrous and weird. Ashamed and dismayed, we ask: who is responsible" (qtd. in Palmisano 20). Heschel's mother was murdered by the Nazis and his two sisters died in Concentration camps. The man who wrote influential works including Man is not Alone, God in Search of Man, The Sabbath and The Prophets considered himself to be a survivor saying: "a brand plucked from the fire, in which my people was burned to death" (Kaplan, Spiritual Radical 282).

The Holocaust happened only seventy years ago, it can be considered recent as it is still within living memory of some. In Modernity and the Holocaust, Zygmunt Bauman, a Polish sociologist writes: "The Holocaust was born and executed in our modern society, at the high stage of our civilization and at the peak of human cultural achievement, and for this reason it is a problem of that society, civilization and culture" (Preface iv). Bauman believes that it was the rational world of modern civilization which provided the necessary condition that made the Holocaust thinkable to the perpetrators. The prerequisites accountable for the nature of tragedy befalling the Jews were many. The first sine qua non was 'prejudice' itself, which found its manifestation in an 'innuendo' or a naive ethnic joke. The people who were different in any way (here the Jews) were not only segregated unjustly but kept outside the bounds of mundane human obligations also. The second proviso was the fallacy that poverty can be eradicated by getting rid of poor people. Lawrence N. Powell writes in The Holocaust and History: Introduction to the Survivors' Stories that "the myth of biological racism was at the root of Hitler's Promethean project of ethnic cleansing and demographic engineering and it still crops up in contemporary civil wars and current day political discourse". The third requisite was numbing the civil courage of masses. The Holocaust transpired in profuse public view and had an abominable culmination because millions chose to be bystanders only. During the apotheosis of Nazism in Germany, the Jews were in a 'minuscule minority' and anti-Semitism was merely a metaphysical concern of Germans. It is true that no venomous acrimony was evident in the streets of Germany for the Jews but the 'Final Solution' took place with the acquiescence of the masses. As the British historian Sir Ian Kershaw has argued that during World War II, most people were aware of the Holocaust, but they were more concerned about the war than the "Final Solution to the Jewish Question" ("Final Solution"). He made the notable claim that "the road to Aushwitz was built by hate, but paved with indifference" (Kershaw). In 1700's Edmund Burke, an Irish political philosopher has 
submitted that all that is necessary for evil to triumph is for good men to do nothing and a plethora of incidents from the history substantiate it.

History is not simply a narration of 'series of events' but chronicles of human lives are embedded in it. For several years after the World War II, the survivors of the Holocaust were fanatically cautious to verbalize their personal experiences. They refused to talk about their previous lives believing recalling such an offence would be distressing. Among the survivors, there was a sense of commotion due to the unresolved mourning for the missing members of the family and community. There was a curtain of silence holding back the past which was lifted slightly in 1961 following the publicity surrounding Adolf Eichmann's trial. Even then the survivors did not come to terms with their own mortality but they resolved to speak when 'contested Holocaust denial' by certain obdurate groups defamed the experience of the survivors and dishonoured the memory of those perished. This disbelief, incomprehensibility, obscurity and exclusivity exist through much of the writings of the Holocaust. The survivors of this savagery record their perplexity at the facts they are trying to hold and fathom; and their disbelief when withstanding their own memories of persistent persecution. In his diary, a Ghetto archivist Chaim Kaplan illustrates how "it is beyond his pen to describe the destruction" (qtd. in Lothe 7).

Elie Wiesel displays the inability of the survivors to recount their experiences when he submits, "between our memory and its reflection there stands a wall that cannot be pierced" (qtd. in Sobanet Introd. 22). A survivor of Buchenwald, Jorge Semprun, refrained from writing for several years believing how could he convey the truth of that barbarism in a 'straight' testimony. He wished that there should be invention of literary tools to express such a beastly experience. Elie Wiesel's much quoted statement, "A novel about Aushwitz is not a novel, or else it is not about Aushwitz" (qtd. in Bloom 23) finds relevance as in his writings Aushwitz figures prominently in the memory of the survivor protagonist. While receiving Nobel Peace Prize in 1986 as "a messenger to mankind" (Pariser 40) and "a human being dedicated to humanity"(Aickman 354) he explained that he resolved to write as the world knew what was happening in the concentration camps but nobody neither cared nor dared to do anything. "That's why I swore never to be silent whenever and wherever human beings endure suffering and humiliation" asserts Wiesel (qtd. in Pariser 40). His words, in his works echo his life's endeavour "for the dead and the living, we must bear witness" (Pariser 43) are carved in stone at the U.S. Holocaust memorial Museum in Washington D.C. Night is Wiesel's lifelong, passionate dedication to ensure that the world never forgets man's capacity for inhumanity to man. Night eloquently addresses many of the philosophical as well as personal questions implicit in any serious consideration of what the Holocaust was, what it meant, and what its legacy is and will be. This autobiographical masterpiece is a heart breaking memoir. In All Rivers Run to the Sea, Wiesel explicitly says that it is not a novel, but his deposition:

Never shall I forget those flames which consumed my faith forever.

Never shall I forget that nocturnal silence which deprived me, for all eternity of the desire to live.

Never shall I forget those moments which murdered my soul and turned my dreams to dust.

Never shall I forget those things, even if I condemned to live as long as God Himself. Never. (183)

Primo Levi was a promising Italian chemist who was captured at the age of twenty four by the Nazis in 1943 and kept alive because of his scientific prowess. Nicholas Patruno in his write up "Primo Levi: Surviving the Holocaust" calls him prisoner number 147517 and submits that the title of his first book Survival in Aushwitz, Levi suggests Levi's triumph over Holocaust. In the epigraphic poem of the book, that is derived from Hebrew Prayer 'Shema' he asks whether anyone in this world has the right to disgrace and torture any human being the way he and his peers have been treated in Aushwitz. He further questions the readers, whether he, Primo Levi, despite all he had endured, and emerged alive from such an horrendous experience, still be considered a human being by them with his integrity and mental faculties intact. Levi's responsibility to be a witness for those who perished impelled him to write and this 'guilt of survival' motivated him to accomplish this self appointed obligation. In an interview to Gail Soffen he submits. "To tell the story, to bear witness, was an end for which to save one self. Not to live and to tell, but to live in order to tell..." (Levi, Beyond Survival 12-13).

Viktor E. Frankl's memoir Man's Search for Meaning: An Introduction to Logotherapy unfolds his chilling but inspirational battle in the Aushwitz concentration camp for survival. Reiterating his experiences he submits: "This book does not claim to be an account of facts and events but of personal experiences which millions of prisoners have suffered... inside story of a concentration camp told by one of its survivors" (Frankl 2). In the concentration camp every circumstance taught him that man's primary force of motivation is his search for meaning of life. Gordon W. Allport in the Preface of the book by Frankl asks:

As a long time prisoner in bestial concentration camps he found himself stripped to naked existence.

His father, mother, and his wife died in camps or were sent to the gas ovens, so that, excepting for his 
sister, his entire family perished in these camps. How could he - every possession lost, every value destroyed, suffering from hunger, cold and brutality, hourly expecting extermination - how could he find life worth preserving ? A psychiatrist who personally has faced such extremity is a psychiatrist worth listening to ..... Frankl's words have a profoundly honest ring for they rest on experiences too deep for deception. (7-8)

Frankl submits that he survived because "all that oppressed me...... became objective.... I succeeded somehow in rising above the situations, above the sufferings. Both I and my troubles became the object of an interesting psychoscientific study undertaken by myself" (82). He quotes Spinoza from Ethics: "Affectus, qui passio est; desinit essepassio simulataque eius claram at distinctam formamus ideam (qtd. in Frankl 82) which means... "Emotion, which is suffering ceases to be suffering as soon as we form a clear and precise picture of it (82). This book has its object "to weave the threads of a life into a firm pattern of meaning and responsibility" (98). A 'tragic optimism' keeps one optimistic despite of pain, guilt and death in one's existence. A human being has the potential to turn suffering into a human achievement and accomplishment. Further one can derive from the guilt the opportunity to change oneself for the better. "Life is potentially meaningful under any conditions, even those which are most miserable," (139). To make the best out of any given situation is Frankl's message here. A book can lie around for years in a book shelf like any other non living object, but it comes to life as soon as it is read, interpreted and understood by any reader.

As insistent as the survivor memoirist is on establishing evidence of the crimes against him and his people it might be said that, like the diarist victim who documented his own activity as diarist, the memoirist documents nothing more persuasively than his own existence after the Holocaust. The survivor's literature thus becomes testimony not so much to the deaths at Aushwitz but to his life after Aushwitz. A survivor's writing after the Holocaust is proof that he has defeated the "final solution". It is indisputable evidence that he now exists, a notion that no survivor ever takes for granted. (Frankl 150)

M.H. Abrams describes in A Handbook of Literary Terms that in a memoir ".... the emphasis is not on the author's developing self but on the people and events that the author has known or witnessed, and also from the private diary... which is a day-to-day record of the events in one's life, written foe personal use and satisfaction..." (31).

Mendel Mann asserts in Writing and Rewriting the Holocaust: Narrative and the consequences of Interpretation that "I write to prove that I am, that I exist, that I too am still on the planet. The world condemned me to die. I write because, through my books, I bear witness to my existence" (Young 72). For Mann writing is the ultimate assertion of 'self' over the 'experience', it is a refutation of all that might have consumed him.

In his essay on Kafka in Language and Silence, George Steiner states: "The world of Aushwitz lies outside speech as it lies outside reason. To speak of the unspeakable is to risk the survivance of language as creator and bearer of humane, rational truth. Words that are saturated with lies or atrocity do not easily resume life" (123). It attributes to the fact that the atrocities of the 'Third Reich' are unspeakable literally and trauma of Aushwitz can not be expressed adequately because their immanent brutality goes beyond the referential and representational competence of any language.

Irving Howe in his book, Writing and the Holocaust begins his essay on Holocaust writings with a recognition of how their subject itself "resists the usual capacities of the mind" (424). Howe further discusses famous and much debated statement of Theodor Adorno that, "After Aushwitz ....to write a poem is barbaric" (qtd. in Howe 355). Howe corroborates his assertion by submitting that it is an unimaginable ordeal ".... to squeeze aesthetic pleasure out of artistic representation of the naked bodily pain of those who have been knocked by rifle butts...." (Howe 434). But Howe supports the realistic proclamations of witnesses through their writings: "Holocaust writings make their primary claim, I would say, through facts recorded or remembered" (430). Howe further submits in support of his view that:

Reading Holocaust memories we respond not just to their accounts of what happened ; we respond also to qualities of being, tremors of sensibility we respond, most of all, to a quality that might be called moral poise, by which I mean a readiness to engage in a complete reckoning with the past, in so far as there can be one.... (431)

This 'moral poise' asserts that going through these writings we necessarily appraise the experiences of the narrator by developing a penetrating in sight.

Lawrence Langer published his book The Holocaust and the Literary Imagination in 1975 arguing that the testimonies of the Holocaust survivors are the ultimate source of truth. In an essay on "The question of 
Aesthetics in Holocaust Literature and Criticism" in the edited book After Testimony: The Ethics and Aesthetics of Holocaust Narrative for the Future, Langer's point of view is supported.

He took as his corpus literacy works by writers who had lived through the Holocaust, either as Survivors of persecution (ranging from camp survivors like Wiesel or Semprun to children who had lost their parents or their whole families, like Yakov Lind or Andre Schwarz - Bart) or as bystanders or even soldiers in the the German army (like Heinrich Boll). (59)

Langer deliberated that there writers have produced genuine literary works based on their first hand experiences and accomplished the transmutation of an appalling, gruesome reality into verbal craft proficiently.

The exclusivity of the Holocaust from any other historical event is reasonably peculiar of Holocaust Studies. It has been observed that the extermination of Jews was engulfed by an aura of obscurity, a denial or even inability of representation, and there was a total rejection of theoretical tools otherwise used when dealing with any other chronicled history piece. The Holocaust is thus described as an abject event that is explained as an exemplar outside space and time. So this literature of survivors is indeed their anguish finding manifestation into testimony for the sake of those who cannot testify for themselves and there protest that the world kept silent. In her modern classic The Fountainhead, Ayn Rand contests that it becomes the hardest thing to explain when everybody decides not to see the glaringly evident.

In his Nobel Peace Prize Acceptance Speech in Oslo on December 10, 1986 Elie Wiesel quotes the bewilderment of the young Jewish boy: "This is the twentieth century, not the Middle Ages. Who would allow such crimes to be committed? How could the world remain silent?" (A Jew Today 118). And thus he resolves to take sides and not to endure suffering and humiliation silently. He submits that "we must take sides. Neutrality helps the oppressor, never the victim. Silence encourages the tormentor, never the tormented. Sometimes we must interfere. When human lives are endangered, when human dignity is in jeopardy...." (Wiesel A Jew Today 118).

These memoirs give an incisive, interpretive account of the lives lost in the worst crime of the 20th century civilization. Therefore, in this civilized world there should not be any quarters for the persecution of human beings because of their race religion or political views. There should a commitment to protect the rights of minority groups as this commitment evolves the cornerstone of our civic creed.

\section{Works Cited}

[1]. Abrams, M. H. A Glossary of Literary Terms. 7th ed. Rpt. 2006. New Delhi: Thomson (Heinle), 2006. Print.

[2]. Aickman, David. Great Souls. Nasville: Word Publishing, 1998. Print.

[3]. Bauman, Zygmunt. Modernity and the Holocaust. New York: Cornell U P, 2001. Print.

[4]. Bloom, Harold, ed. Literature of the Holocaust. Philadelphia: Chelsea House, 2004. Print.

[5]. "Final Solution." Wikipedia: The Free Encyclopedia. Wikimedia Foundation, Inc. 9 Jan. 2014.Web. 10 Jan. 2014.

[6]. Frankl, Viktor E. Man's Search for meaning: An Introduction to Logotherapy. 1959. 4 th ed. Boston: Beacon, 1992. Print.

[7]. Howe, Irving. Writing and the Holocaust: Selected Writings, 1950-1990. New York: 24 Harcourt, Brace, Jovanwich, 1991. Print

[8]. "Ian Kershaw”. Wikipedia: The Free Encyclopedia. Wikimedia Foundation, Inc. 7 Jan. 2014. Web. 4 Jan. 2014.

[9]. Kaplan, Edward K. Spiritual Radical: Abraham Joshua Heschel in America (1940-1972). New Haven: Yale U P, 1996. Print.

[10]. - --. Holiness in words: Abraham Joshua Heschel Poetics of Piety. Albany: State University of New York P, 1996. Print.

[11]. Langer, Lawrence. The Holocaust and the Literary Imagination. New Haven: Yale U P, 1975. Print.

[12]. Levi, Primo. "Beyond Survival." Prooftexts 4.1 (June 1984): 12-13.

[13]. ---. Survival in Aushwitz. Trans. Stuart Woolf. New York: Collier, 1969

[14]. Lothe, Jakob, et al, eds. After Testimony: The Ethics and Aesthetics of Holocaust Narrative for the Future. Columbus: Ohio State U P, 2012. Print.

[15]. Marrus, Michael. The Holocaust in History. Toronto: Keyporter, 2000. Print.

[16]. Palmisano, Joseph. Beyond the walls: Abraham Joshua Heschel and Edith Stein on the significance of Empathy for Jewish Christian-Dialogue. New York: Oxford U P, 2012. Print.

[17]. Pariser, Michael. Elie Wiesel. Brook field: Millbrook Press, 1994. Print.

[18]. Patruno, Nicholas. "Primo Levi: Surviving the Holocaust." N.d. Web. 8 Jan. 2014.<http://www.brynmawr.edu/italian/holoc/essays/surv hol.htm>.

[19]. Powell, Lawrence N. The Holocaust and History: Introduction to the Survivors' Stories. 1999- 2014. Web. 8 Jan. 2014. <www. holocaust survivors. org./data>.

[20]. Rand, Ayn. The Fountainhead. London: Bobbs-Merrill, 1943. Print.

[21]. Rothberg, Michael. Multidirectional Memory: Remembering the Holocaust in the Age of Decolonization. Stanford: Stanford U P, 2009. Print.

[22]. Sobanet, Andrew. Jail Sentences: Representing Prison in Twentieth-century French Fiction. London: U of Nebraska Press, 2008. Print.

[23]. Steiner, George. Language and Silence: Essays 1958-1966. London: Faber and Faber, 1967. Print.

[24]. Weisel, Elie. A Jew Today. Trans. Marion Wiesel. New York: Random House, 1978. Print.

[25]. ---. All Rivers run to the Sea. New York: Knopf Doubleday, 2010. Print.

[26]. ---. Night. London: Hill and Wang, 1960. Print.

[27]. Young, James. The Texture of Memory: Holocaust Memorials and Meaning. New Haven: Yale U P, 1993. Print.

[28]. ---. Writing and Rewriting the Holocaust: Narrative and the Consequences of Interpretation. Bloomington: Indiana U P, 1988. Print. 